\title{
ISIDORO DE SEVILHA E A CONSTRUÇÃO DE UM CONCEITO DE MONARQUIA TEOCRÁTICA NO REINO VISIGODO
}

\section{ISIDORE OF SEVILLE AND THE CONSTRUCTION OF A CONCEPT OF THE MONARCHY THEOCRATIC IN THE VISIGOTH KINGDOM}

\begin{abstract}
Pâmela Torres Michelette ${ }^{1}$
RESUMO: Este artigo teve como objetivo compreender a elaboração da concepção da Realeza católica a partir das ideias políticas do bispo Isidoro de Sevilha (560-636). Prelado que viveu na passagem do século VI para o VII na Hispânia Visigoda, um período de mudanças, onde se buscava a unidade religiosa, política, legal, administrativa e de identidade deste reino. Coube a Isidoro de Sevilha traçar-lhe a doutrina. Assim analisamos as perspectivas deste prelado em relação ao reinado de Recaredo, rei que apareceu diante do III Concílio de Toledo (589) como o autor da conversão de seu povo e defensor dos interesses da única Igreja oficial do reino, bem como de seus sucessores. Contudo, apesar da conversão de Recaredo ter dado um novo caráter à Monarquia esta ainda não conseguiu consolidar totalmente o reino. Isidoro, através de suas obras desenvolveu um importante papel na tarefa de fortalecimento da Monarquia. Assim na maior parte de seus escritos não apenas apresentou as preocupações e anseios de um indivíduo isolado, mas os desejos e temores também do restante do corpo que, em sua maioria, compunham a Igreja hispano-visigoda e a instituição monárquica. Outro ponto que abordaremos foram alguns dos elementos que constituíram o desenvolvimento teórico que culminou com a formulação de um nítido conceito de poder de Monarquia teocrática e o papel preponderante da Igreja Hispânica e de Isidoro nesta elaboração.
\end{abstract}

PALAVRAS-CHAVE: Reino Visigodo; Isidoro de Sevilha; Monarquia; Igreja; Recaredo.

ABSTRACT: This article sought to understand the development of the conception of the royalty Catholic from ideias of Isidore of Seville (560-636). Bishop who lived in the passage from the sixth century to seven in Hispania, a period of change, where the sought the unit, religious, political, legal, administrative and identity of this kingdom. It was up to him to draw his doctrine. Thus we analyze the prospects of this prelate over the reign of Reccared, king who appeared before the Third Council of Toledo (589) as the author of the conversion of his people and defending the interests of the one Church official of the kingdom as well as their successors. However, despite the conversion Reccared have given a new character to the monarchy that has yet to fully consolidate the kingdom. Isidoro, through his works developed an important role in the task of strengthening the monarchy. So in most of his writings not only presented the concerns and desires of an isolated individual, but also the desires and fears of the rest of the body ecclesiastical of the Church Catholic and the monarchical institution. Another point to discuss some of the elements that were formed the theoretical development that culminated in the formulation of a clear concept of power theocratic monarchy and leading role of Hispanic Church and Isidoro this development.

KEY-WORDS: VISIGOTHIC Kingdom; Isidore of Seville; Monarchy; Church; Reccared.

(recebido em 20/01/2013, aprovado em 01/05/2013)

Mestra em História Medieval pela UNESP (Campus de Assis/SP). Este trabalho é resultado da nossa pesquisa de Dissertação de Mestrado, intitulada: "A Concepção de Realeza Católica Visigoda e as ideias políticas de Isidoro de Sevilha". Docente da Faculdade Santa Izildinha (FIESI/UNIESP). 
Temos como objetivo principal neste artigo identificar como o ambiente do reino visigodo, no século VII, influenciou a construção das ideias políticas de Isidoro de Sevilha ${ }^{2}$, pois, acreditamos que este bispo procurou estabelecer, em alguns de seus trabalhos, uma conduta moral direcionada a Monarquia visigoda. Ou seja, desenvolveu uma concepção teológica política vinculada ao princípio de que a realeza ${ }^{3}$ está a serviço da lgreja ${ }^{4}$.

Acreditamos assim que Isidoro de Sevilha, através de alguns de seus trabalhos, foi um dos principais responsáveis pela construção da teoria política relativa à Monarquia visigoda, bem como a solidificação e normatização dessa instância de poder. O bispo sevilhano viveu durante um período de transformações no qual se buscava a unidade religiosa, política, legal, administrativa e de identidade do reino. Esse ambiente teve forte influência na edificação de suas ideias. Em razão de sua força e de sua riqueza intelectual e episcopal, ele exerceu uma preeminência sobre o reino visigodo e seus príncipes ${ }^{5}$. A personalidade e atividades singulares de Isidoro de Sevilha não podem ser compreendidas sem termos presentes as circunstâncias que envolveram a sua vida e obra.

No que tange a doutrina e os conceitos políticos formulados pelo bispo, acreditamos que foi uma tentativa de traçar o perfil de príncipe ideal, espelhando-se, inicialmente, em Recaredo (568-601) rei que oficializou o catolicismo niceísta no reino e que para o sevilhano reunia as principais

2 Isidoro de Sevilha (560-636). Pertenceu a uma família católica de origem bizantina ou hispano-romana. Como bispo de Sevilha, o irmão de Isidoro, Leandro de Sevilha, foi o instrumento decisivo para conseguir a renúncia oficial ao arianismo dentro do reino visigodo, proclamada no III Concílio de Toledo. Isidoro sucedeu a Leandro como bispo por volta de 600 e, durante o seu bispado, Sevilha desfrutou de preeminência como centro intelectual do reino visigodo. Ver mais, entre outros, em: LOYN, H. R. Dicionário da Idade Média. Rio de Janeiro: Jorge Zahar, 1997, p. 212-213; QUILES, Ismael S. I. San Isidoro de Sevilla, Biografia-Escritos-Doctrina. Madrid: Espasa - Calpe, 1965; URBEL, P. San Isidoro de Sevilla. Su vida, su obra y su tiempo. León: Labor, 1995.

3 Uma boa noção de sacralidade é o verbete de V. Valeri, "Realeza". Aqui, Valeri afirma que o que define a Realeza é o fato de que no exercício de suas prerrogativas, o rei encarnaria os valores fundamentais da sociedade sobre a qual ele reina, sendo considerado como um ser sagrado e às vezes divino: "Mesmo quando o rei não é sagrado stricto sensu, ele tem relações privilegiadas com aquilo que é sagrado: Deus ou clérigo que é seu intérprete". Cf: VALERI, V. "Realeza". In: R. Romano (ed). Enciclopédia Einaudi. Religião-Rito, Lisboa: Casa da Moeda, 1994, v. 30, pp. 415-445, especialmente, p. 415.

4 Cabe lembrar que entendemos Igreja neste artigo como uma instituição de características locais, apesar de seus componentes afirmarem pertencerem a um grupo maior. Cf: RAINHA, R. S. A educação no Reino Visigodo - as relações de poder e o epistolário do bispo Bráulio de Saragoça (631-651). Rio de Janeiro: HP Comunicações, 2007, p. 28. Madrid: Encuentro, 2002, p. 99 
características favoráveis de um bom governante. Desse modo, esta elaboração consistiria em um modelo de conduta governamental político-religiosa a ser seguido pelos reis que sucedessem 0 supracitado monarca ${ }^{6}$.

Neste sentido, percebemos que o perfil do rei visigodo-católico foi desenhando-se progressivamente pelos padres e concílios de inspiração doutrinal isidoriana, até compor uma imagem elaborada. Recaredo, o precursor, encarnou essas virtudes, porém não faltaram no século VII outros soberanos que foram considerados por seus contemporâneos e pelo próprio bispo de Sevilha como virtuosos governantes e exemplares príncipes católicos ${ }^{7}$.

O grande problema que se colocou a Isidoro de Sevilha, e a seus contemporâneos, foi saber qual caminho tomar depois da conversão. Em outros termos: qual o significado da realeza em uma sociedade cristã? Não se tratava apenas de definir as relações entre Igreja e Monarquia no momento em que esta última procurava seu caminho. Era importante revesti-la de uma justificação ideológica. ${ }^{8}$ Neste sentido, tentaremos evidenciar as principais categorias do pensamento isidoriano, como: os valores intelectuais e morais, políticos e religiosos; tentando esclarecer a elaboração de uma cultura, que não podemos afirmar como inovadora, mas renovada e atualizada para o momento em que tanto a Igreja como a Monarquia estavam vivenciando.

\section{O pensamento político de Isidoro de Sevilha e o conceito de Monarquia idealizada}

O teórico Isidoro de Sevilha foi quem deu alguns dos aspectos do pensamento político visigodo, tendo dois pólos de influência: o mundo clássico e a Igreja. Esta última constituía um grande reino e os seus regentes deveriam dar apoio aos sacerdotes, quando estes não conseguissem se impor apenas pelas palavras.

O pensamento político do sevilhano repousa no princípio de que a realeza está a serviço da Igreja. Nesse sentido, a Monarquia não era entendida como uma falsa imitação do Império, mas sim Estudios Medievales. sl.: Fundacion Sanchez Albornoz, 1993, pp. 55-64, p. 57.

$7 \quad$ IDEM, Ibidem, p. 63-64.

8 RIBEIRO, D. V. A sacralização do Poder Temporal: Gregório Magno, e Isidoro de Sevilha In: Souza, José Antônio de C. R. (org.). O Reino e o Sacerdócio - O pensamento político na Alta Idade Média, s/d. pp. 91-112, p. 109. 
como uma instituição a serviço da causa cristã, segundo a vontade de Deus ${ }^{9}$. Desta forma, há duas fontes de poder para a concepção de realeza na concepção de Isidoro: Deus e o povo cristão. É Deus quem dá o poder, mas o rei é também convocado pela comunidade de fiéis.

Dessa forma, temos uma realeza fundada na comunhão de fiéis ${ }^{10}$. Tal sistema político parte da afirmação de que a Igreja constitui o regnum Christ, o que permite afirmar, segundo Marc Reydellet, que a teologia política de Isidoro era cristológica por primazia ${ }^{11}$.

Não podemos deixar de lado a influência que o platonismo teve para a Patrística. Suas ideias foram propagadas no âmbito político do Ocidente, ressaltando a plenitude do governante, como sábio e justo. Desta forma, a Igreja, que se tornou poderosa, não deixou de lado essas concepções. Contudo elas passaram por análises muito profundas para resgatarem apenas o que fosse necessário aos preceitos da Igreja. A filosofia da Antiguidade era caracterizada como uma duvidosa busca pela verdade divina.

Assim, a Patrística realizou amplos estudos que convergiam e divergiam entre o platonismo e 0 cristianismo. Deste modo, Agostinho de Hipona, Gregório Magno, Isidoro de Sevilha, entre outros, receberam essa influência cultural dos filósofos da antiguidade que refletiam as "(...) virtudes cardeais de justiça, temperança, coragem e prudência teorizadas por Platão e Aristóteles" ${ }^{12}$ e que foram incorporadas ao modelo ideal para os bons governantes.

Acreditamos ser pertinente, aqui, fazermos pequenas observações sobre Gregório Magno e santo Agostinho. 0 momento histórico em que o primeiro exerceu seu pontificado foi um período conturbado, em que a Europa medieval estava florescendo, por isso, ele tentou estabelecer uma política entre Igreja e os governantes. Neste sentido, o mesmo utilizou-se de elementos das Sagradas Escrituras e da obra de Santo Agostinho, especialmente da Cidade de Deus. Entretanto, cabe destacar que apesar de Gregório ter sido um discípulo das ideias deste Padre da Igreja, segundo D. V. Ribeiro, não se tornou tão pessimista como Agostinho. Lembrando que este último viveu em um período que o

$9 \quad$ IDEM, Ibidem, p. 106.

10 REYDELLET, M. La royauté dans la litterature latine de Sidonio Apollinaire à Isidore de Séville. Roma: École Française de Rome - Palais Farnése, 1981, p. 592-593.

11 O sistema político-religioso isidoriano parte da afirmação de que a Igreja constitui o regnum Christi e, portanto, a realeza de Cristo. IDEM, Ibidem, p. 557. 
Império sofria com as invasões, enquanto que o papa teve que se relacionar com esses novos reinos germânicos e procurar impedir uma fragmentação religiosa, tentando unificar esses povos sobre uma única religião ${ }^{13}$.

Isidoro não foi um autor de uma teoria própria e de nenhum sistema novo, mas seu reconhecimento vem de seu trabalho de selecionar e coordenar os materiais que eram da Antiguidade, com destaque para Aristóteles, e os autores que contribuíram para a filosofia cristã, especialmente Agostinho de Hipona e o papa Gregório I $^{14}$.

Santo Agostinho defendia que Deus deu suas leis a humanidade por meio dos reis. Dessa forma, o pensamento agostiniano considerava que o ofício real era como um ofício eclesiástico, já que a concepção de Igreja como um corpo, deu um suporte importantíssimo para este processo, pois a função do monarca era baseada dentro de uma concepção teleológica. O que, na prática, transformava-se no exercício das obrigações reais, tanto no âmbito do reino como da Igreja. Dessa forma, surgiu o entendimento do conceito de officium, ficando claro, assim as intenções da Igreja de interferir no âmbito do poder monárquico.

Essa concepção de que o governante está a serviço dos preceitos da Igreja defendidos por santo Agostinho, tem relação com as suas experiências, em virtude dele perceber a fragilidade em que o Império romano se encontra e que esse necessitava da Igreja, para que essas duas instituições pudessem garantir a paz. Desta forma, o bispo defendia que esta cooperação seria útil em questões que pudessem colocá-las em risco.

Muitas das ideias e pensamentos do sevilhano foram inspirados também em Gregório Magno. O papa acreditava que a Igreja e a Monarquia deveriam se unir para alcançar uma unidade, ou seja, um assistência mútua. Mas para conquistar tal propósito essas duas instâncias de poder não podem se sobrepor à outra.

A Monarquia deve ficar subordinada a Igreja no que dizia respeito à matéria espiritual, e a Igreja sujeita aos negócios temporais, delegando esta responsabilidade ao poder régio. Assim, os dois poderes, em caso de necessidade, podem sair de seu domínio para assumir o do outro, neste sentido

13 IDEM, Ibidem, p. 25-26, no prelo.

14 QUILES, I. S. I. Op. cit., p. 79. 
haveria situações em que ambas as instituições se tornariam inseparáveis ${ }^{15}$. Aqui, trazemos a baila Daniel V. Ribeiro. Este autor defende a tese de que Isidoro seguiu os preceitos gregorianos e agostinianos para a formulação de uma Monarquia idealizada. Dessa forma, cabe destacar:

\begin{abstract}
Parece que Isidoro considera a exegese de Gregório mais adequada a moral política que ele tenta impor no reino ibérico. É impelido a Gregório possivelmente por razão particular. A ótica de duas cidades em confronto de Santo Agostinho reflete a observação de um mundo pagão; a perspectiva de Gregório e Isidoro é a de uma sociedade cristã. A transferência que se processa aplica-se ao novo povo de Deus, isto é, o povo cristão. [...] ao ideal do rex [grifo do autor] ou à doutrina do mau rei, o pensamento isidoriano fundamenta-se intimamente em Gregório Magno. ${ }^{16}$
\end{abstract}

Para Isidoro de Sevilha a procedência divina do poder real constituiu-se a ideia básica de seu pensamento político, uma concepção que identificamos resumida na expressão gratia diuina ${ }^{17}$, em especial quando faz referência ao rei visigodo Suintila. Conceito que mostra que a força régia, era resultado de um favor celestial, através da graça divina. Ou seja, o poderio régio se instituiu para que as leis fossem cumpridas. Para Isidoro as leis eclesiásticas não eram exceções, ou seja, a realeza também estava a serviço da Igreja.

Este deveria utilizar sua autoridade coercitiva quando as leis canônicas não fossem eficazes em seu cumprimento através da palavra. Dentro dessa concepção, o monarca estava obrigado a compromissos espirituais dentro de suas funções temporais ${ }^{18}$. A Igreja, dessa forma, tentava fazer deste poder não um privilégio, mas um serviço a ser exercido em benefício da coletividade, considerando este recurso governamental como mais um instrumento de salvação.

15 URBEL, P. Op. cit., p. 243.

16 RIBEIRO, D. V. O pensamento político de Isidoro de Sevilha. In: Estudos Ibero-Americanos, V. XV, $n^{\circ} 2, P^{2}$ PC-RS, 1989, 347-355.

17 ALONSO, Cristóbal Rodriguez. La Historia de Los Godos, Vandalos y Suevos de Isidoro de Sevilla. Leon, Centro de Estudios e Investigacion "San Isidoro" Archivo Histórico Diocesano, Caja de Ahorros y Monte de Piedad de Leon, $1975,62,2-4$, p. 274-275. 
Assim, para o bispo sevilhano o poder do rei tinha uma tarefa determinada: procurar que se cumprissem às leis. $O$ poder monárquico deveria estar sempre em função do bem dos súditos. $A$ validade do poder, segundo o bispo, não era perdida com o mau rei, isso porque a perda de legitimidade somente poderia ser julgada por Deus. De acordo com esse autor, o rei estava submetido às leis como qualquer um de seus súditos.

Para Daniel V. Ribeiro, o pensamento de Isidoro foi dominado por um desejo de "unificação", que não deve confundir-se com um projeto teocrático. Pode-se até admitir uma negação do direito natural, mas não uma absorção da Monarquia pela Igreja. Certamente, ao atribuir ao poder temporal função religiosa, a doutrina eclesiástica gerou certa confusão entre os poderes ${ }^{19}$.

Peter Brown em sua obra "O fim do mundo clássico" expõe que os bispos foram aqueles que mais trabalharam pelo estabelecimento da Igreja cristã na sociedade romana:

[...] apascentam o seu rebanho com a férrea energia dos governadores coloniais de um território "atrasado". Querem que os imperadores cristãos os ajudem. A partir do reinado de Teodósio I, os pagãos e os heréticos são privados de direitos civis e obrigados a conformarem-se com a Igreja católica. O Estado Romano tem uma missão transcendente, afirma-se, e o imperador é responsável perante Deus pelas almas dos súditos. ${ }^{20}$

P. Brown deixa-nos claro que não apenas os monarcas tinham que assumir compromissos com Deus, mas os bispos também, já que da mesma forma possuíam cargo de responsabilidade perante a Igreja. Talvez seja esse o encargo que Isidoro sentia quando assumiu uma postura de tutor no reino visigodo ao lado do poder régio. Ele não tinha apenas o papel de instruir, mas o de fazer parte do plano da salvação, já que o sevilhano aconselhou os reis, participou efetivamente de reuniões conciliares e escreveu múltiplas funções que talvez tivessem propósitos bem definidos. No que diz respeito ao 
Ocidente, este mesmo autor defende que tais concepções enfraqueceram seus governantes, pois eles se tornaram suscetíveis aos desejos da Igreja, o que não ocorreu no império do Oriente ${ }^{21}$.

Cabe destacar, que ocorreram mudança na questão de concepção da origem divina dos governantes. Principalmente, quando os imperadores deixaram de se considerarem divinos e passaram a defender as bases de seus poderes na Graça divina. W. Ulmann defende que esta alteração foi importante, pois estes abandonaram as aspirações de serem divindades na terra e reconheceram que Deus era a origem do poder. Esta modificação pode ser atribuída à doutrina paulina, que alterou tais práticas $^{22}$.

Isso alterou também a relação das eleições reais visigodas, no qual, inicialmente, o rei era constituído por votação. Posteriormente, elas deixaram de possuir o mesmo significado, pois as concepções de poder pela vontade divina, fizeram com que os pleitos ganhassem um outro propósito: 0 de apenas escolher um indivíduo idôneo para desempenhar tal cargo. Sendo assim, a eleição não lhe dava poderes, não o fazia rei, apenas a unção e a coroação lhe conferiam o poder divino e legitimava seu status perante todo o reino ${ }^{23}$.

Assim podemos perceber que Isidoro não teve o propósito de caracterizar a Monarquia visigoda como teocrática. Entretanto essa demonstrou, em diversos âmbitos, elementos que a definiam como tal, tendo a Igreja como suporte para tal aparato teórico.

\section{A Monarquia Teocrática}

Muito já foi escrito a respeito das teorias elaboradas pelas autoridades eclesiásticas com 0 objetivo de afirmar a legitimidade da Monarquia visigótica. Sobre esse tema podemos identificar algumas abordagens que servirão de suporte para analisar a complexa realidade teórica da realeza. Outro ponto que analisaremos serão as atribuições adquiridas pela Monarquia visigoda com relação à

$21 \quad$ IDEM, Ibidem, p.114.

22 ULLMANN, W. Principios de gobierno y política en la Edad Media. Madrid: Alianza Editorial, 1985, p. 61.

23 ULLMANN, W. Historia del pensamiento político en la Edad Media. Barcelona: Ariel, 1983, p. 130; ULLMANN, W. Op. cit,, 1985, p. 149-151. 
formulação da teoria teocrática sobre o governo, observando o que lhe foi conferido no âmbito temporal e religioso.

Teremos como objetivo perceber como o ambiente do final do século VI e princípios do VII influenciou na construção de uma concepção de Monarquia católica idealizada, através dos escritos do bispo Isidoro de Sevilha.

Com a conversão, a Monarquia visigoda transformou-se em uma Monarquia católica e a Igreja Ihe proporcionou uma sólida base conceitual em que se fundamentou sua autoridade. Os prelados foram quem monopolizaram a cultura e elaboraram a teoria político-religiosa que serviu de base e legitimou a autoridade real, adquirindo os monarcas, desta forma, um substrato teocrático e ideológico. Aqui, achamos pertinente, lembrar que uma das características das ideologias é que elas são sistemas completos e globalizantes, ou seja, apresentam à sociedade elementos de seu passado, presente e futuro em um conjunto que caracteriza uma visão de mundo ${ }^{24}$.

Neste sentido, o monarca visigodo, que já era responsável pelo poder temporal, assumiu 0 compromisso, também, dos assuntos espirituais, em virtude de ele ter como dever supremo a direção da sociedade cristã. Isidoro, entendido neste trabalho como representante da Igreja Visigoda, tentou basear seus escritos dentro de uma perspectiva cristã, inspirado em autores que defendiam uma união entre a lgreja e os governantes. Portanto, a realeza estava a serviço da Igreja e de um plano de salvação, uma vez que o rei era um enviado divino. Sendo assim, tudo se encaixava dentro de uma estrutura e concepção de mundo muito bem articulada pelo sevilhano, mas que na prática não teve grandes impactos.

Outro elemento que destacamos ainda com relação à ideologia é o seu caráter deformante, ou seja, apesar de aparentar uniformidade, ela é a junção de "inflexões, escapatórias e distorções" que mascaram algumas características que são muitas vezes as verdades de interesses particulares, mas que estas não podem vir à tona para não romper com o que está consolidado ${ }^{25}$. Desta forma, podemos identificar estas características quando a rivalidade das três instâncias (Monarquia, Igreja e Nobreza),

24 DUBY, G. História social e ideologia das sociedades. In LE GOFF, J; NORA, P. (Dir) História: Novos Problemas. Rio de Janeiro: Francisco Alves, 1979, pp.130-145.p. 132. 
no qual cada uma tentou fortalecer seus interesses que estavam relacionados com a conquista de espaço e poder dentro do reino visigodo.

Além dessa deformação que a ideologia pode conter, ela também compete com outros sistemas de representações, ou seja: "refletem antagonismos que por vezes nascem da justaposição de etnias separadas, mas que são sempre determinadas pela disposição das relações de poder"26. Assim, no caso do reino visigodo antes da conversão com Recaredo, Leovigildo acreditava que a melhor opção de unificação do reino seria através do arianismo, mesmo em uma sociedade que em peso era do credo niceísta. Não podemos esquecer que os elementos imperiais que foram incorporados por Leovigildo à realeza também serviram de base para que a lgreja e o rei estabelecessem as estruturas de uma Monarquia com características divinas.

A cristianização da Monarquia trouxe elementos de uma teoria político-religiosa, cuja principal ideia foi a procedência divina do poder régio. Mas, para a pesquisadora M. Valverde de Castro, essa concepção de origem divina do poder não foi originária da Igreja visigoda:

La sacralización de la autoridad monárquica tiene un origen muy remoto. $\mathrm{E}$. Benveniste, al estudiar la formación del término rex y la aparición de la realeza indoeuropea, descubre que la misión del rey era, en un principio, mucho más religiosa que política. En las primitivas monarquías del mundo mesopotámico, griego, hebreo, y romano se constata el fuerte carácter sacerdotal que poseían los reyes. [...] entre los primitivos germanos la autoridad pudo tener originariamente un marcado carácter sacral. Ahora bien, la concepción del poder temporal como procedente de la divinidad que se va a imponer en el reino visigodo del s. VII tiene sus raíces en la literatura cristiana del Bajo Imperio. Fue en el s. IV, y debido a la progresiva identificación entre la Iglesia y el Império Romano, cuando, en el marco de una concepción cristiana de la sociedad y de la Historia, se formularon una serie de teologias políticas que sancionaron el carácter teocrático del emperador. La identificación del emperador con el vicario de Dios en la tierra, su función como guardián supremo de la unidad de la fe y de la Iglesia, el paralelismo que se establece entre el gobierno universal divino y el imperial y, por tanto, la necessidad de que exista un único poder supremo que se identifique con la cabeza del cuerpo social, la creencia de que el poder terrenal ha sido instituído por la divinidad para corregir las consecuencias del pecado..., son ideas presentes en Eusebio de Cesarea, Agustín de Hipona o Ambrosio de Milán que constituyeron los princípios 
políticos que sustentaron la autoridad del emperador cristiano en el mundo bajoimperial $[\ldots]^{27}$

Um dos postulados da Monarquia teocrática foi que o rei era considerado a máxima autoridade no âmbito judicial. Entretanto, nem sempre dispôs dos mecanismos para que se fizessem cumprir as leis que ditava. P. D. King defende que nenhum outro aspecto de governo cumpriu diretamente seu papel singular de teocrático como o da promulgação de leis. Segundo este autor, a lei era produto somente de sua vontade.

[...] el rey disfrutaba de lo que podríamos llamar verdadeiro absolutismo legislativo en cuanto que no necesitaba de la participación de otros y en cuanto que llevaba sobre si la responsabilidad inmediata, personal y total de su creación. ${ }^{28}$

Para P. D. King a conversão ao catolicismo também favoreceu a aparição de um direito comum de aplicação geral para o conjunto da população hispano-visigoda, segundo este autor:

la unidad de todos los cristianos em uma sola ecclesia visigoda se convirtió em uma fuerza poderosa actuando em favor de la unidad del derecho. De hecho el próprio Recaredo promulgo leyes obligatorias para todos los habitantes del reino. ${ }^{29}$

Cabe frisar que W. Ullmann, no que diz respeito às leis, faz referência ao princípio de concessão, já que cabia ao poder real conceder direitos aos seus súditos que, de outra forma, não possuiriam; ou seja, era a ideia da graça real na prática. Este poder tinha origem superior e era transmitido através do ato de concessão. Sendo assim, ao rei foi concedida sua posição e ao súdito

27 VALVERDE CASTRO, M. R. Ideología, simbolismo y ejercicio del poder real en la monarquía visigoda: un proceso de cambio. Salamanca: Ediciones Universidad de Salamanca, 2000, p. 196.

28 KING, P. D. Derecho y sociedad en el reino visigodo. Madrid, Alianza, 1981, p. 71.

$29 \quad$ IDEM, Ibidem, p. 157. 
seus direitos, ambas as conquistas em virtude da Dei gratia ${ }^{30}$. Apesar de o governo ter características de absoluto, não equivalia a um governo arbitrário, pois o rei não podia omitir os preceitos divinos.

Outro elemento desta Monarquia se manifestou no âmbito militar, como afirma M. Valverde de Castro "las victorias reales se obtienen gracias a la ayuda de Dios y los fracasos militares se explican como castigos divinos por la mala actuación de los reyes" ${ }^{\prime 31}$. Isso ficou evidente no discurso de Isidoro na História dos Godos em que ele relaciona os êxitos ou fracassos militares dos reis ao fato deles possuírem ou não virtudes cristãs. A teoria política que legitimava todas as atuações do soberano, também validava seus poderes militares, segundo M. Valverde Castro:

El juramento prestado por el monarca al acceder al trono determina que sea tarea del rey velar por la seguridad del reino y consagrarse a la propagación de la paz. [...] de la misma manera que es una función específicamente regia la dirección de las relaciones diplomáticas del reino con el exterior $[\ldots]^{32}$

Todavia, em teoria o rei visigodo tinha plenos direitos com relação ao exército, mas na prática careceu em alguns momentos de meios necessários para exercer as amplas atribuições militares que a teoria político-religiosa the concedia. A realidade sócio-econômica causava empecilhos, os exércitos privados haviam aumentado consideravelmente em número e importância, desta forma, diminuindo a autoridade do monarca sobre as tropas. Para M. Valverde Castro, isso se deu, em virtude, do processo de ruralização que a sociedade visigoda havia passado e ao aumento de autonomia e poder conquistado por grupos nobiliárquicos ${ }^{33}$.

No que tange a administração, o rei, apesar de exercer o poder, tinha a necessidade de delegar parte de suas competências a uma série de pessoas ou de instituições que pudessem colaborar para o bom funcionamento do governo. Ou seja, a função de guardião do reino e dos súditos, não poderia ser cumprida sem a colaboração de outros membros que pudessem dar um suporte nas

$30 \quad$ ULLMANN, W. Op. cit,, 1985, p. 124.

31 VALVERDE CASTRO, M. R. Op. cit., p. 233.

32 IDEM, Ibidem, p. 233.

33 IDEM, Ibidem, p. 233-236. 
áreas executiva, militar e de arrecadação de impostos. 0 monarca não cumpria com todas essas atividades; foi confiada a ele a tarefa de proteger e zelar pelo seu povo. Por isso ele precisava confiar em outros $^{34}$. Assim, nas palavras de P. D. King:

su proprio control y participación en todos los aspectos del gobierno permanecia siempre como una consecuencia necesaria de su suprema responsabilidad ante Dios, pero no tenia outra responsabilidad sino confiar en otros para llevar adelante el peso de la obra. ${ }^{35}$

Segundo o mesmo autor, a máquina administrativa do reino era composta por um órgão central, a corte régia e pela organização provincial, da qual o rei estava à frente. Apesar da autoridade monárquica estar presente, essa delegação de poderes implicou inevitavelmente em uma grave limitação da supremacia teórica e prática do monarca.

Contudo, a nomeação de determinados cargos era de exclusiva competência do rei. Essas concessões, segundo M. Valverde Castro, foram consequências da forma teocrática do governo do século VII. Ou seja, Deus era a única fonte de poder, por isso concedeu-o ao rei e este, em exercício de real graça, redistribui este poder entre seus súditos que, neste caso, foi na forma de cargos administrativos ${ }^{36}$.

No que diz respeito às nomeações eclesiásticas, os monarcas intervieram na titulação dos bispos. Esta prática não era institucionalizada, mas se tornou frequente dentro do reino visigodo. Deste modo, podemos perceber que essa atribuição limitava o poder político que possuía o episcopado, em virtude dos bispos atuarem diretamente no âmbito da administração local.

Já o capital régio do reino contava com algumas fontes fundamentais de recursos: a grande reserva de bens preciosos que constituíam o "tesouro real"; as rendas provenientes das terras que pertenciam ao patrimônio da coroa, as confiscações; e os impostos de origem pública, arrecadados entre a população sujeita a tributação. Da mesma forma que, na teoria, uma Monarquia teocrática era

KING, P. D. Op. cit., p. 71-72.

35 IDEM, Ibidem, p. 71-72.

36 VALVERDE CASTRO, M. R. Op. cit., p. 236-237. 
obrigada a nomear bons juízes, também era função do bom rei evitar que os funcionários que possuíssem atribuições fiscais cometessem abusos ao exercerem o poder que thes era confiado. Contudo M. Valverde Castro demonstra que na prática não ocorreu desta forma:

El fuerte proceso de feudalización que está sufriendo la sociedad visigoda implico que los grandes propietarios laicos y eclesiásticos fueran adquiriendo paulatinamente mayor poder y mayor autonomía respecto a la maquinaria estatal, lo que se tradujo en que, si no en teoría, al menos de facto, las grandes propiedades estuvieran exentas de tributos. Ello, inevitablemente, provocaba el descenso del patrimonio fiscal, y cada vez más los reyes visigodos se vieron obligados, por un lado, a recurrir a sus propios recursos para satisfacer los gastos estatales $\mathrm{y}$, por outro, a recurrir a las confiscaciones, más que a la tributación, para engrosar los bienes de que dispone el Estado, la Monarquia. El impuesto, de hecho, ha dejado de ser el fundamento económico del Estado ${ }^{37}$.

Outra prerrogativa adquirida pelo monarca visigodo, no âmbito econômico foi o direito exclusivo de cunhar moedas.

No que tange as atribuições alcançadas pela Monarquia, destacamos a convocação dos concílios, a autonomia de decidir os principais temas que seriam discutidos e a confirmação das decisões tomadas neles. Segundo E. A. Thompson, na relação Monarquia e autoridades eclesiásticas, o rei era dominante. Tal conclusão baseia-se na comparação entre a importância real e as decisões conciliares.

Este pesquisador chama-nos a atenção para o fato de que algumas das deliberações conciliares estavam em conformidade com as instruções dadas pelos monarcas. Assim, os bispos se limitavam, na maioria das vezes, a confirmar as decisões tomadas pelo rei. Embora os concílios servissem também como instrumento político, tal aspecto se restringia a legitimar uma posição previamente decidida, ou seja, os bispos não desafiavam o governante. $O$ autor com essa conclusão não minimiza a importância política dos concílios, embora esses nem sempre fossem relevantes para dar maior autoridade ao $\mathrm{rei}^{38}$.

$37 \quad$ IDEM, Ibidem, p. 241.

38 THOMPSON, E. A. Los Godos en España. Madrid: Alianza Editorial, 1971. 
A pesquisadora M. Valverde Castro concorda em alguns aspectos com Thompson. Para esta autora, a autoridade régia de convocar sínodos, de decidir os assuntos a serem tratados e as decisões tomadas nestes eventos evidenciam que os reis contavam com poderes suficientes para submeter sob seu controle qualquer atuação dos concílios, que para ela eram o órgão máximo de decisão da Igreja hispânica ${ }^{39}$.

No que se referem aos concilios provinciais, estes se tornaram obrigação dos bispos metropolitanos, e não do monarca e deveriam ocorrer anualmente. Esse critério foi estipulado no III Concílio de Toledo, no cânone XVIII:

Manda este santo y venerable concilio que conforme a lo prescrito en los cánones antiguos que ordenaban reunir los concílios dos veces cada año, en atención a la lejanía y pobreza de las iglesias de España, los obispos se reúnan tan solo una vez al año en el lugar elegido por el metropolitano. ${ }^{40}$

Em contrapartida a decisão do concílio, o historiador Walter Ullmann parte da perspectiva de que a Monarquia medieval apresentava características teocráticas. $O$ autor aponta as particularidades teóricas que explicavam a origem do poder monárquico. Esse poder, primeiramente, foi de origem ascendente, isto é, vinha do povo para os governantes. Em um segundo momento, o poder assumia o caráter descendente, ou seja, de Deus para o governante. O monarca tinha poderes em virtude da Dei gratia. Outros aspectos podem ser levantados, a partir dos apontamentos do mesmo autor, para permitir tal definição: as concessões do monarca aos súditos de direitos que de outra forma estes não possuiriam; a obrigação de manter a paz no reino (a paz do rei); e, por fim, a influência da vontade do soberano na escolha de bispos e na convocação de concílios eclesiásticos ${ }^{41}$.

VALVERDE CASTRO, M. R. Op. cit..

40

CONCILIOS VISIGÓTICOS E HISPANO-ROMANOS. Ed. bilíngüe (latim-espanhol) de J. Vives. Barcelona-Madrid: CSIC, 1963. Cf. concílio: III Toledo (589), c. XVIII.

41 ULLMANN, W. Op. cit, 1985. W. Ullmann focou a maioria de seus trabalhos no estudo de direito canônico e nas teorias políticas medievais, realizando uma análise geral dos principais pressupostos teóricos da Idade Média Ocidental. Ainda que este trabalho trate de aspectos gerais, é de grande importância para os estudos relativos à política visigoda, p. 121-141. 
A Monarquia teocrática necessitou de um ritual de reconhecimento por parte da Igreja, que se deu, sobretudo, a partir da unção régia. Tal cerimonial, segundo W. Ullmann, colocou o monarca dependente do poder religioso, uma vez que ele era ungido por um membro da alta hierarquia eclesiástica. Era oficial o reconhecimento da Igreja para a consolidação do poder real.

Uma vez imposta à prática da unção régia no reino visigodo, realizada em Toledo, o ato consagratório desse ritual converteu-se na cerimônia mais importante que marcava o inicio do reinado de um monarca visigodo. Frisa-se o fato de ocorrer em Toledo como uma forma de diferenciar um governante legítimo de outro ilegítimo.

P. D. King analisa a teoria política do reino visigodo. Sua visão aproxima-se em alguns pontos com a de W. Ullmann, principalmente, ao caracterizar a Monarquia visigoda como teocrática, pois ambos os autores partem do princípio teológico da origem do poder. O primeiro justifica a compreensão do poder monárquico a partir da teoria existente no período medieval: da mesma forma como Deus criou a cabeça na parte superior do corpo humano, organizadora das ideias e comandante das ações, também colocou o rei na cabeça do corpo da sociedade, a fim de que possa governar os súditos. Em virtude disso, o rei se encontraria em posição superior aos que, por divina disposição, estavam submetidos a seu domínio. Embora P. D. King tenha, em muitos momentos, um discurso religioso, sua hipótese gravita em torno da noção de que a realeza ocupou um lugar acima ao das autoridades eclesiásticas ${ }^{42}$.

P. D. King ainda defende que a Monarquia visigoda teve características cesaropapistas, pois apesar dos clérigos declararem nos concílios as normas de conduta cristãs e ditarem as medidas disciplinares, essas assembleias, em inúmeras ocasiões, foram convocadas pelos reis. Outro argumento considerado pelo autor foi que os cânones não iam contra a vontade régia, bem como 0 fato da legislação conciliar ser uma sugestão do mesmo. No que diz respeito à instabilidade da Monarquia, P. D. King expõe:

El poder y la avidez de más poder de los maiores fue la constante realidad política con que, a pesar de su condición teocrática, tuvieron siempre que contar los reyes y 
el escollo contra el que naufragaría tristemente una política que tan sólo se basó en la supremacía teórica de la realeza ${ }^{43}$.

E. H. Kantorowicz, em sua célebre analise presente na obra "Dois Corpos do Rei", demonstrou que a metáfora em que o rei era a cabeça e os súditos os membros permeou o pensamento político durante a Alta Idade Média. Ele procurou evidenciar que a doutrina da teologia e da lei canônica definia para a Igreja e a toda a sociedade cristã, principalmente para os reinos recém-convertidos ao catolicismo, que eles faziam parte de um corpus mysticum, em que a cabeça era Cristo, porém isso foi perpassando do âmbito teológico para o poder político, cuja cabeça se tornou o rej ${ }^{44}$.

Apesar de E. H. Kantorowicz trabalhar com o período da Inglaterra elisabetana, consideramos que é de extrema importância suas ideias, já que o próprio autor coloca que não é possível analisar este período sem retomar as informações que vieram dos primeiros séculos da era cristã, em decorrência das similaridades de discurso e do pensamento desses dois períodos da história. Desta maneira, podemos perceber que essa transição de definições de uma esfera a outra, ou seja, da teologia para o direito, não foi nada inovadora. Assim, o aproveitamento de características teológicas para delinear o Estado foi sendo desenvolvido durante vários séculos, da mesma forma que nos primórdios da era cristã, a terminologia política imperial e cerimonial do mesmo foi adaptada aos anseios da lgreja 45 .

Teodoro Gonzalez diverge das colocações dos demais autores aqui expostos, pois não compreende a Monarquia visigoda como teocrática, uma vez que esse pesquisador considera uma Monarquia teocrática quando o rei desempenha atribuições equivalentes a dos sacerdotes. Baseandose nos apontamentos de Isidoro de Sevilha, o autor afirma que o fato do soberano ter sido designado por Deus para cumprir o plano divino de salvação humana, não significa que o monarca estava, como indivíduo, acima dos outros homens, uma vez que na relação com Deus todos são seus súditos. Os

IDEM, Ibidem, p. 70.

KANTAROWICZ, E. H. Os dois corpos do rei - Um estudo sobre teologia política medieval. São Paulo: Companía das Letras, 1998, p. 26. 
reis não receberam de Deus o privilégio da "impecabilidade" e nem eram considerados mediadores entre os homens e Deus, papel esse que era de propriedade da Igreja ${ }^{46}$.

Nesta perspectiva, o soberano não estava acima do poder religioso, mas submetido tanto à Igreja como às leis. Na concepção de T. Gonzalez, são amplos os limites da autoridade secular. Sua análise é interessante, pois propõe um direcionamento que se distancia da historiografia acerca dessa questão, apesar de não considerar a dinâmica política como fator determinante para se compreender 0 período. O que na nossa opinião faz com que seus argumentos não sejam suficientes para descaracterizar a Monarquia visigoda como teocrática.

A origem divina do poder monárquico, assim como sua missão de salvação que desenvolveu o soberano, foram as bases ideológicas que sustentaram as amplas atribuições adquiridas pela Monarquia no interior da Igreja hispânica. Não havendo uma clara separação entre religião e política no reino, o nítido conceito de poder, já existente no século VII, pode legitimar e consolidar a realidade do poder monárquico, que em sua origem no período tolosano era uma realeza errante, imprecisa e não permanente e que tinha como estrutura outros conceitos de legitimação.

Entretanto a Monarquia visigoda, apesar de ter 0 aporte teórico dos princípios teocráticos vigentes, em finais do século VI e princípios do VII, na prática, a elevada posição econômico-social dos grupos nobiliárquicos e da Igreja, os converteram em importantes núcleos de poder político que de fato impediram que a realeza pudesse exercer uma autoridade quase ilimitada que o subsídio teórico lhe concedia.

O processo de fortalecimento e consolidação da instituição monárquica foi concomitante ao processo que se deu com relação à nobreza visigoda, desta forma, acarretando uma contradição estrutural, sendo o fortalecimento ideológico da Monarquia insuficiente para subordinar esses grupos em determinados momentos da história do reino. Como observou M. Valverde Castro "La formulación teórica sobre el poder hizo fuerte a la institución de gobierno monárquica, pero no a la persona que ocupaba el trono" 47 . Assim o efetivo governo ficou a cargo de algumas particularidades como a

46 GONZÁLEZ, T. La Iglesia desde la conversión de Recaredo hasta la invasión arabe. In. GARCIA VILLOSLADA, R. (Org.) Historia de la Iglesia en España. La Iglesia en la España Romana y Visigoda (siglos I-VIII). V. I. Madrid: BAC, 1979, p. 432-447. 
personalidade, a capacidade de riquezas, os vínculos pessoais, e as circunstâncias históricas concretas que cada rei teve.

Outro ponto que realçamos dentro desta caracterização de Monarquia teocrática, diz respeito ao espaço territorial, segundo J. A Maravall um dos requisitos fundamentais para poder se falar de uma Monarquia territorial é a existência de um amplo espaço em que se exerce o governo de um único poder soberano. Mas esta área tem que estar unificada. Assim, após o processo de identificação territorial, alcançado por Leovigildo e concretizado na prática por Suintila, cumpre um dos requisitos para se alcançar o qualitativo de unidade territorial. Já que foram atingidos outros pontos como a unificação populacional, jurídica e religiosa, portanto concretizando o espaço como unitário48.

Além desses elementos mencionados anteriormente alguns outros foram empregados para singularizar a Monarquia visigoda, implantadas especialmente no governo do rei Leovigildo, que foram a utilização de insígnias régias, como o cetro, o traje purpúreo e a coroa, foram os recursos mais utilizados. Desta forma, podemos observar, mais uma vez a aproximação da Monarquia visigoda aos emblemas majestáticos usados pelos imperadores romanos e bizantinos.

A utilização desses símbolos imperiais pelos reis visigodos coloca em evidência o forte impacto que os "usos imperiais" causaram não apenas no reino toledano, mas no restante das Monarquias germânicas. Além disso, demonstra a necessidade de integrar-se a esse mundo considerado por eles culturalmente superior. Neste sentido, a busca pela aproximação dos comportamentos imperiais fez com que os monarcas visigodos tentassem se equiparar aos imperadores, manifestando assim seu caráter soberano e independente, tanto nas questões externas quanto internas. No âmbito exterior, lutar contra 0 avanço bizantino e conseguir manter a independência; e no interior se diferenciar e se sobrepor à nobreza, demonstrando, desta forma, o distanciamento entre o governante e o governado.

Essa prática de reutilizar a cultura de povos vizinhos ou estrangeiros está fortemente relacionada aos sistemas ideológicos, esse conjunto cultural que foi utilizado tornou-se a base dessas ideias e práticas disseminadas, como foi o caso do Império Romano para a Monarquia visigoda.

Essas representações ideológicas apresentam uma realidade simplificada da organização social, deixando de lado as variantes, superposições e as dificuldades, "(...) acusando pelo contrário os 
contrastes e acentuando as hierarquias e os antagonismos"49. Neste caso, reforçando os malefícios das sublevações e seus tiranos. Apesar de montar um sistema que pode trazer uma ordem estabilizadora concomitantemente, fortalece-se pelas contradições que a realidade impõe, justificando, desta forma, tais posturas que são colocadas como as melhores opções para serem resolvidos os problemas internos com seu modelo de perfeição com aval divino.

\section{Bibliografia}

\section{Fontes Primárias:}

CONCILIOS VISIGÓTICOS E HISPANO-ROMANOS. Ed. bilíngüe (latim-espanhol) de J. Vives. Barcelona-Madrid: CSIC, 1963.

\section{Referências Bibliográficas:}

ALONSO, Cristóbal Rodriguez. La Historia de Los Godos, Vandalos y Suevos de Isidoro de Sevilla. Leon, Centro de Estudios e Investigacion "San Isidoro" Archivo Histórico Diocesano, Caja de Ahorros y Monte de Piedad de Leon, 1975.

BROWN, P. O fim do mundo clássico - De marco Aurélio a Maomé. Lisboa: Editorial Verbo, 1972.

DUBY, G. História social e ideologia das sociedades. In LE GOFF, J; NORA, P. (Dir) História: Novos Problemas. Rio de Janeiro: Francisco Alves, 1979, pp.130-145.

FONTAINE, J. Isidoro de Sevilla: Génesis y originalidad de la cultura hispánica en tiempos de los visigodos. Madrid: Encuentro, 2002.

GONZÁLEZ, T. La Iglesia desde la conversión de Recaredo hasta la invasión arabe. In. GARCIA VILLOSLADA, R. (Org.) Historia de la Iglesia en España. La Iglesia en la España Romana y Visigoda (siglos I-VIII). V. I. Madrid: BAC, 1979.

KANTAROWICZ, E. H. Os dois corpos do rei - Um estudo sobre teologia política medieval. São Paulo: Companía das Letras, 1998.

KING, P. D. Derecho y sociedad en el reino visigodo. Madrid, Alianza, 1981.

LOYN, H. R. Dicionário da Idade Média. Rio de Janeiro: Jorge Zahar, 1997. 
MARAVALL, J. A. El concepto de España en la Edad Media. Madrid, Centro de Estudios Constitucionales, 1981.

ORLANDIS, J. "El rey visigodo catolico", in. AA. VV., De la Antigüedad al Medievo - Siglos IV-VIII. III Congreso de Estudios Medievales. sl.: Fundacion Sanchez Albornoz, 1993, pp. 55-64.

QUILES, Ismael S. I. San Isidoro de Sevilla, Biografia-Escritos-Doctrina. Madrid: Espasa - Calpe, 1965.

RAINHA, R. S. A educação no Reino Visigodo - as relações de poder e o epistolário do bispo Bráulio de Saragoça (631-651). Rio de Janeiro: HP Comunicações, 2007.

REYDELLET, M. La royauté dans la litterature latine de Sidonio Apollinaire à Isidore de Séville. Roma: École Française de Rome - Palais Farnése, 1981.

RIBEIRO, D. V. A sacralização do Poder Temporal: Gregório Magno, e Isidoro de Sevilha In: Souza, José Antônio de C. R. (org.). O Reino e o Sacerdócio - O pensamento político na Alta Idade Média, s/d. pp. 91-112.

. O pensamento político de Isidoro de Sevilha. In: Estudos Ibero-Americanos, V. XV, ${ }^{\circ} 2$, PUCRS, 1989, 347-355.

Realeza cristã e ideologia na Alta Idade Média. pp. 1-33, no prelo.

THOMPSON, E. A. Los Godos en España. Madrid: Alianza Editorial, 1971.

ULLMANN, W. Historia del pensamiento político en la Edad Media. Barcelona: Ariel, 1983.

Principios de gobierno y política en la Edad Media. Madrid: Alianza Editorial, 1985.

URBEL, P. San Isidoro de Sevilla. Su vida, su obra y su tiempo. León: Labor, 1995.

VALERI, V. "Realeza”. In: R. Romano (ed). Enciclopédia Einaudi. Religião-Rito, Lisboa: Casa da Moeda, 1994, v. 30, pp. 415-445.

VALVERDE CASTRO, M. R. Ideología, simbolismo y ejercicio del poder real en la monarquía visigoda: un proceso de cambio. Salamanca: Ediciones Universidad de Salamanca, 2000. 